\title{
Introduction: Turning to the visual in digital discourse studies
}

Thurlow, Crispin ; Dürscheid, Christa ; Diémoz, Federica

DOI: https://doi.org/10.1515/9781501510113-001

Posted at the Zurich Open Repository and Archive, University of Zurich

ZORA URL: https://doi.org/10.5167/uzh-184329

Book Section

Published Version

Originally published at:

Thurlow, Crispin; Dürscheid, Christa; Diémoz, Federica (2020). Introduction: Turning to the visual in digital discourse studies. In: Thurlow, Crispin; Dürscheid, Christa; Diémoz, Federica. Visualizing digital discourse : interactional, institutional and ideological perspectives. Berlin, Boston: De Gruyter, 1-17. DOI: https://doi.org/10.1515/9781501510113-001 


\section{Crispin Thurlow and Christa Dürscheid Introduction: Turning to the visual in digital discourse studies}

\section{Setting the scene}

In a chapter titled 'New frontiers in interactive multimodal communication' for a handbook on Language and Digital Communication, internationally renowned scholar of language and digital media Susan Herring (Herring, 2015: 402) remarks on the need for scholars to develop more properly multimodal approaches to computer-mediated communication. This is what she says: "An approach needs to be developed that analyzes disparate modes in relation to one another, ideally with a common set of research questions, methods, and so forth, to permit meaningful comparisons across modes and across platforms." An approach such as this, Herring goes on to explain, requires attending to the way different modes interact (or not) in different digital texts and contexts.

It is precisely this understanding, indeed this empirical reality, which motivates our volume here. Although we do not claim to offer a monolithic approach or even a common set of research questions, we believe Visualizing Digital Discourse is the first dedicated volume of its kind which brings together the work of language and communication scholars committed to understanding the role of visuality (and multimodality) in the context of digital media. The volume showcases the work of leading scholars, established scholars and emerging scholars from across Europe, and addresses a diverse range of digital media platforms (e.g. messaging, video-chat, social media, gaming, video-sharing, photo-sharing), communicative settings (e.g. interpersonal, commercial, institutional), visual modalities (e.g. written language, typography, emojis, photography, video, layout) and methodologies (e.g. discourse analysis, corpus-based analysis, social semiotics, ethnography, conversation analysis) and languages (e.g. French, German, Italian, English, Finnish). Throughout, contributors are specifically focused on understanding the particular role of visual communication in (or about) these digital media platforms as a way to better understand how linguistic and communicative practices are multimodally accomplished. Sometimes visual resources (e.g. typography, photos, emojis, video) are central, at other times they are incidental; regardless, they are always integral to the servicing of people's interactional, institutional and/or ideological objectives. 
Whether online or offline, digitally mediated or face-to-face, everyday communicators take up and combine different 'semiotic resources' (cf. van Leeuwen, 2005) in ways which are sometimes creative, sometimes strategic, but always purposeful and meaningful.

As its title suggests, Visualizing Digital Discourse is situated primarily within that field of research known as computer-mediated discourse analysis (e.g. Herring, 2007, 2013), new media sociolinguistics (e.g. Danesi, 2016) or just digital discourse studies (see Thurlow, 2018). We will not rehearse the literature here; suffice it to say, however, the study of linguistic and communicative practices in the context of digital media is now well established. This is also a field which has historically been driven by edited collections, starting with Susan Herring's (1996) ground-breaking Computer-mediated Communication: Linguistic, Social and Crosscultural Perspectives. (Our volume's sub-title is styled partly to pay homage to her volume.) Other productive takes on the field include the volumes by Thurlow \& Mroczek (2011), Jones, et al. (2015), Georgakopoulou \& Spilioti (2015a), Squires (2018) and, most recently, Bou-Franch \& Garcés-Conejos Blitvich (2019). Still within English-language scholarship, a number of important journal special issues have likewise helped drive the field; notably, for example, Androutsopoulos (2006) and Androutsopoulos \& Beißwenger (2008). The range of perspectives represented in our volume responds either directly or indirectly to the kinds of issues and recommendations proposed over the years by these collections and special issues, as well as by prominent scholars like Susan Herring (ibid.), Jannis Androutsopoulos (e.g. 2011a), Naomi Baron (e.g. 2010), Lauren Squires (e.g. 2010), and so on. We certainly recognize from amongst this field, the scholarship of Rodney Jones (e.g. 2009), lead contributor to the current volume. We might even mention some of our own contributions over the years: Crispin Thurlow (e.g. 2006, 2014, 2018) and, especially in the German-language world, Christa Dürscheid (e.g. Dürscheid et al., 2010; Jucker \& Dürscheid, 2012). While trying to keep up with the latest technological changes, digital discourse studies has constantly sought to stay current, undertaking a number of key theoretical and methodological 'turns'. One of the most notable of these was a turn towards more situated (e.g. ethnographic) studies of new-mediated linguistic and communicative practices. As indicated in the Herring quote above, we are beginning to witness rising scholarly interest in - a turn towards - the inherent, unavoidable multimodality of digital media.

In some ways, multimodality should always have been a taken-for-granted in new media sociolinguistics. It is certainly nowadays regarded as a core concept in sociocultural linguistics and discourse analysis more generally (e.g. Jewitt, 2004; Kress \& van Leeuwen, 2001; Scollon, 2001; and, especially, Norris \& Jones, 2005). 
Often, however, a lot of digital discourse scholarship continues - perhaps not altogether surprisingly - to be structured by its disciplinary focus on language and linguistic phenomena. The increasingly multi-media and inherently multimodal nature of digital communication makes this single-track, and sometimes single-minded, approach more and more untenable (see Georgakopoulou \& Spilioti, 2015b, for a similar point of view). As we say, this is especially germane given the growing complexity of the multi-media formats of newer new media, brought about by the inevitable convergence of old and new media (cf. Jenkins, 2006) and the layering of new media with other new media (cf. Androutsopoulos, 2011; Myers, 2010). Regardless, digital discourse studies is certainly in need of advanced analytical equipment if it is to keep track of the changing significance (in both common senses of the word) of language in the synaesthetic (cf. Kress, 2003) and heteroglossic (cf. Androutsopoulos, 2011b) spaces of digital media. A fully multimodal analysis will, of course, require an even wider scope than the one we offer here; nonetheless, we hope Visualizing Digital Discourse, with its special attention to visuality, begins to point the way.

There are certainly good reasons for opening up digital discourse studies to a broader multimodal perspective, as Thurlow (2017) has recently attested. The most obvious of which lies in simply paying more attention to visual communication per se. We know well, for example, that even word-based digital discourse is often as much visual as it is linguistic, concerned as much with the look of words as with their semantic or stylistic properties (e.g., Vaisman, 2014). In addition to research on issues like orthographic and typographic design, however, there is certainly some useful work being done on the communicative uses of visual resources such as emoji, video, GIFs, and non-moving images (see Highfield \& Leaver, 2016, for a useful review). In this regard, we note two good examples of research in precisely this direction: Androutsopoulos and Tereick (2015) and Dürscheid and Siever (2017). Beyond these moves, there is also value in considering metadiscursive perspectives; in other words, research which examines how visuality in digital discourse is talked about by everyday users. By the same token, scholars might examine how digital media are visually represented in, for example, commercial advertising, print or broadcast news, cinema and television narratives and/or public policy and educational settings. Certainly, and as Thurlow and his colleagues have shown (Thurlow, 2017; Thurlow, Aiello \& Portmann, 2019), visual discourse encodes and combines a range of influential media and semiotic ideologies. Again, Visualizing Digital Discourse addresses both these ways of approaching visuality from a metadiscursive angle. 


\section{Organization of the book}

The current volume has its origins in a conference Visualizing (in) the New Media hosted by the co-editors in November 2017 as part of a four-year, multiparty research project funded by the Swiss National Science Foundation (see Acknowledgments). The co-editors lead two of the projects' constituent subprojects. Definitely not a conference proceedings, our volume represents a carefully, competitively curated selection of papers initially presented at the conference. To start, the initial rejection rate for conference papers was about 20 to $25 \%$. We started with chapters by the conference's three original keynote speakers (Jones, Leppänen and Stöckl), all internationally regarded scholars in their own right. We then solicited and accepted a further seven chapters based on work initially presented at the conference; these chapters reported novel research findings and/or cohered nicely around our three core perspectives on visuality in digitial media (see below). These seven chapters were also selected based on a review of full drafts submitted competitively, with a rejection rate of some $35 \%$. Finally, two additional chapters were specially commissioned, including one co-authored by editor Crispin Thurlow.

Visualizing Digital Discourse is organized into three main sections. Following this short introduction, we open with a powerful framing chapter by Rodney Jones, one of the world's leading scholars working at the interface of sociolinguistics, digital media studies, and multimodal discourse studies. As a casestudy examination of selfies and surveillance culture, Jones' chapter sets the scene perfectly with regards the volume's scholarly focus and critical stance. Each subsequent section of the book opens with a chapter by a prominent, established scholar of digital/visual discourse studies. We provide more detailed summaries of all the chapters below, but we first offer the following potted account of the book's organization.

In Part 1 (Besides Words and Writing), we have three chapters which center on micro-level communicative practices but also from macro-level perspectives. Focusing on the poster child of new-media visuality - emojis - the chapters offer, respectively, a metadiscursive, theoretical, and quantitative approach. In their chapter, Crispin Thurlow \& Vanessa Jaroski take up the cultural politics introduced by Jones. Drawing on an archive of multilingual news stories, they consider the emergence of a discourse of 'language endangerment' whereby emjois are viewed as a threat to words. Specifically, they pinpoint three rhetorical tactics and then examine the kinds of semiotic ideologies this discourse reinscribes. In the next chapter, Georg Albert takes up issues of semiosis by asking what kind of communicative mode emojis are, whether they function like words or images or something in between. With illustrative examples, he attempts to answer the 
question by considering how emojis signify or make meaning in practice. In their chapter, Rachel Panckhurst and Francesca Frontini take things to the ground by looking at actual uses of emoticons/emojis in a very large corpus of SMS messages; they identify their three key functions and examine their grammatical significance. Together, these three chapters establish the inherent, complex multimodalities of digital discourse, while surfacing some of the cultural-political and theoretical challenges in making sense of digital life beyond or besides language.

In Part 2 (The Social Life of Images), we have four chapters which focus on the way visual resources are used for managing everyday, personal relations or for personalizing digital discourse anew. In other words, these chapters demonstrate precisely why visual communication really matters to people. In her opening chapter, Sirpa Leppänen examines how different 'styles of visuality' are taken up by everyday social media users - specifically, blogging mothers. She too considers the ideological implications of these visual practices which offer opportunities for parody but which are also rooted in normative judgement. In their chapter, Axel Schmidt and Konstanze Marx provide an interesting link between personal practice and the kinds of institutional practices which are otherwise the focus of Part 3. They examine Let's Plays which are curated online videos of gamers sharing and commenting on their firsthand playing. The authors consider how participants draw on, and combine, linguistic and visual resources for making their videos not only comprehensible (i.e. easy to follow) but also entertaining and watchable. In the next chapter, Dorottya Cserző presents her research on videochat (e.g. Skype) and the way ordinary users take advantage of its distinctive visual affordance for sustaining long-distance contact and intimacy. The specific focus of her analysis are virtual tours (e.g. of a hotel room) conducted between two siblings separated while one of them is travelling away from home. Sticking with the theme of relational maintenance, and in the fourth and last chapter of Part 2, Rebecca Venema and Katharina Lobinger report the results of a 'repertoire-oriented' study in which they interview romantic partners and close friends about their sharing of photos. In effect, the authors offer an empirically-based retort to popular misconceptions about visuality in digital media; in their case, informants report how photos, as both symbolic and material objects, are a central part of their long-term relationships and friendships. In fact, from across the four chapters in Part 2, we have first-hand evidence of everyday visual literacies at work, where visuality is always meaningfully and sometimes skillfully or creatively taken up.

In Part 3 (Designing Multimodal Texts), we have four chapters which examine digital visuality in more obviously institutional or commercial contexts (as opposed to personal or interpersonal ones). The section opens with a chapter 
by Hartmut Stöckl, a leading scholar known for his work on the intersection of media theory and multimodality. In his chapter, he too takes a more theoretical-cum-methodological tack and, like Jones, considers how broader cultural landscapes are being changed by the rise of visuality (cf. Kress \& van Leuween, 2001). Specifically, he demonstrates the role of 'image-centricity' in both old/ print media and new/social media, asking how and what has changed, if anything. In many ways, the remaining chapters all respond to this polemic. In her chapter, Lara Portmann presents a social semiotic analysis of Instagram used for the strategic purposes of corporate marketing; her specific, topical focus is the visualization (and aestheticization) of food by two major grocery chains in Switzerland. Often heralded for their egalitarian, participatory potential, social media here are again implicated in the production of social hierarchies of taste and, thus, of privilege. In a similar vein, the chapter by Jana Pflaeging takes up social networking and, specifically, a viral genre known as the 'listicle'. She presents a diachronic analysis for tracking the shifting multimodal composition of this particular genre, and finds a counter-intuitive (given Stöckl's position) move from images to words. In the final chapter of Part 3, Dorothee Meer and Katharina Staubach examine how credibility is multimodally produced by social media influencers in so-called haul videos on YouTube. As a case-study, they consider the 'osmotic advertising' of one a well-known German influencer targeting young (female) people. Thanks to the four chapters in Part 3, we have evidence for the way images, video and visuality more generally are shifting institutional practice. We also see the role of visual communication plays in blurring boundaries between the personal and the commercial. As such, the book ends how it started, with a view to larger-scale cultural and ideological shifts happening through the visualization of/in digital discourse.

\section{Detailed chapter summaries}

In his 'flagship' chapter, Rodney Jones explores issues around the embodied nature of visual semiotics in the age of the smartphone, in particular, the ways in which people use everyday practices of making images of themselves and others to negotiate both 'being-in-the-world' (Dasein) and 'being-with' (and for) other social actors (Mitsein) (Heidegger, 2008) within various networks of power, status and social control. The rise of the world-wide web, digital imaging and graphic user interfaces in the late 1990s precipitated an intense interest in the fields of sociolinguistics and discourse analysis in multimodal communication, resulting in a range approaches to visual semiotics, including some that 
focused on the impact of image making on issues of power and social identity. The more recent rise of mobile digital communication, supported by digital video cameras and social media platforms such as Instagram and Snapchat, which compel users to constantly produce themselves and their experiences visually and to construe meaning from the visual representations of other people's experiences, presents significant challenges to the 'grammars' of visual communication developed at the turn of the century, forcing analysts to engage more fully with the ways multimodal meaning emerges not from 'signs' per se, but from techno-somatic entanglements in which the most important communicative resource is not what is visible, but communicators' embodied experiences of seeing it. 'Seeing' and 'being seen', in this regard, are never neutral, uninvolved acts: seeing is always entangled with the mediational means through which it is accomplished, with what is seen and what is happening to it, with what seeing does to the watcher and the watched, and with sets of rules and expectations associated with particular contexts, and particular societies, about who has the right to look, and who has the right to be seen. Jones argues that mobile digital photography has opened up possibilities for a more post-representational perspectives on visual semiotics - digital media have forced us to see not just images, but texts in general, along with 'bodies' and 'media' not as objects but as relational categories that intersect in complex moments of action that can only be understood by engaging with how they are lived. Rodney Jones calls for an approach to digital visual communication which combines social semiotics with phenomenology, particularly the post-phenomenological approaches of scholars like Ihde (2001), with the aim of helping us to understand how people use the embodied and affective dimensions of visual communication to negotiate their physical experiences in the world and their relationships with others. In order to illustrate this approach, he applies it to two current practices of digital imaging making: the embodied act of taking selfies, and the practice of using smartphones to record encounters with law enforcement officers. He shows how both 'selfies' and videos of police stops involve social actors performing the experience of seeing and being seen, and argue that this performance can have profound consequences on people's ability to articulate particular versions of the world and their place in it. Central to this ability is the use of technology to negotiate what Mirzoeff (2011) calls 'the right to look'. Claiming the right to look doesn't just mean claiming the right to look at the other. It's also about claiming the right to turn the camera around - to make oneself visible - to say 'look at me. I'm here'. As Mirzoeff (2011, p. 1) puts it: 'the right to look means requiring the recognition of the other in order to have a place from which to claim rights and to determine what is right'. This, Rodney Jones argues, should be the key 
focus of a new semiotics of the visual, not just how people look or what they see, but how they claim the right to look, and the right to be seen.

To open their chapter, Crispin Thurlow and Vanessa Jaroski start by nothing how news-makers commonly maintain an unduly negative perspective on the impact of digital technologies vis-à-vis people's linguistic and communicative practices. With their particular institutional and cultural investment as professional language workers, journalists consistently reproduce language-ideological depictions of digital discourse which exaggerate its newness and distinctiveness, and which erase individual variation, reflexivity and creativity. Against this backdrop, Thurlow \& Jaroski examine an emerging but closely allied metadiscursive framing of digital discourse: the perceived threat to language posed by visual communication and, specifically, emojis. In this case, as they demonstrate, long-standing narratives of linguistic decline or ruin usually attributed to technology are redirected to the deleterious impact of visuality. They refer to this as a discourse of language endangerment (cf. Duchêne \& Heller, 2007). Instead of a concern to defend (minority) languages from other (majority) languages, however, they find language itself being construed as autonomous and superior, and, more importantly, in need of protection from visual communication. Their study draws on in an in-house archive of news stories related to language, communication and digital media and, specifically, a sample of stories from January 2014 to September 2017 imported into AntConc for generating two corpora (French and English). Ultimately, Thurlow \& Jaroski argue that the discourse of language endangerment is one rooted in, and constitutive of, not only language ideologies but also deepseated semiotic ideologies (cf. Keane, 2003). In other words, as Thurlow (2017) has elsewhere argued, popular beliefs about digital media fundamentally misrecognize meaning-making in language, in visual communication, and in the inherently multimodal interplay of the two. In an otherwise visual age and at a time when visual literacies are so key (see Kress \& van Leeuwen, 1996), it is especially problematic (or, at least, unhelpful), they argue, when journalists promote such contradictory, specious ideas about visual communication and about human communicative action more generally.

Quite apparently - as Thurlow \& Jaroski prove - emojis are widely considered to be quintessential examples of visual communication in digital media. However, because any element of a writing system is clearly also a visual sign, Georg Albert argues that a more detailed, nuanced look at the semiotic qualities of signs is important. To this end, in his theoretical rather than empirical chapter he explains why emojis should not be simplistically identified with images; nor, he argues, are they graphemes either. Even though emojis are often thought to compensate for the lack of mimic signs in written discourse, their 
communicative uses are far more complex. Using as illustrative examples of private messages sent by acquaintances or drawn from his previous studies (e.g. Albert, 2015), Albert maps a better way to understand the diversity of visual signs with a semiotically informed focus on the functional dimensions of emojis, and by comparing them to various writing systems. For this, he orients to scholarship on symbols and writing from, for example, Nelson Goodman, Catherine Elgin and Christian Stetter as well as to Rudi Keller's reinterpretation of Charles S. Peirce's typology of signs. Ultimately, he argues, emojis should be understood in terms of the ways they are actually used rather than their origin or outward appearance. As an effect of their usage, for example, emojis have become conventionalized and are frequent features of written discourse. The more conventionalized a sign becomes, the less it resembles a prototypical image; as such, they end up sharing important features with certain customary elements of the writing system. By the same token, emojis are not straightforwardly equivalent to images either. Ultimately, therefore, argues Albert, emojis need to be treated as a phenomenon sui generis.

In their chapter, Rachel Panckhurst and Francesca Frontini examine actual uses of emojis by drawing on a large corpus of French-language textmessages. In their analysis, they pin-point three main usage situations: (a) redundant addition where an emoji is used in addition to written text, but it is not required in order to understand the text; (b) necessary addition where an emoji is also used but its inclusion is necessary in order to avoid misinterpretation; and (c) lexical replacement where an emoji is used instead of a word. Along these lines, Panckhurst \& Frontini find that emojis are used more often redundantly $(66 \%)$ or necessarily (28\%), and sometimes as 'softeners' for lexical replacement (7\%). Syntactically speaking, the positioning of emojis appears in descending order: final closure positions of text-messages and at the end of sentences $(87 \%)$, the middle of messages $(8 \%)$, and at the start of messages (1\%). Then, by using automatic part-of-speech tagging, the authors also examine the immediate grammatical environment of emojis for a more in-depth analysis of linguistic functions which is also cross-compared with sociolinguistic variables (e.g. age, gender). In this regard, for example, they find that emojis are located most often at sentence/message closure (87\%), and serve as boundary markers rather than as referential elements. However, in a comparison of these results with a 2017 questionnaire on French social media usage (Rascol, 2017), the authors note a slight increase of lexical replacement usage (14\%). The chapter concludes by outlining areas for future research such as the need for diachronic comparisons with more recent data coming, for example, from the What's up, Switzerland? (see Ueberwasser \& Stark, 2017), a project of which this volume's editors have been a part. By the same token, Panckhurst \& Frontini 
also point to the value of exploring, amongst other things, intercultural variation and cross-platform differences.

In opening Part 2, Sirpa Leppänen focuses on what she calls 'revisualization' in social media practices. Focusing on Finland-based social media, she discusses how particular 'styles of visuality' are reanimated and subverted in constructions of, and interactions around, the shifting and contested social category of motherhood. Drawing on discourse studies, the study of multimodality and critical sociolinguistics, she examines how social media users/producers revisualize motherhood in often parodic ways. Accordingly, Leppänen argues that these revisualizations end up challenging neo-conservative ideological assumptions concerning the nuclear family and notions of good mothering. They also challenge the aesthetics of home purported in such popular social media genres as the 'homing blogs' of young women who have created highly aestheticized life journals of their home-based lives and lifestyles (see Jäntti et al., 2017). Ultimately, and following the work of Thurlow \& Jaworski (2017) on elite discourse, Leppänen argues that social media parodies of motherhood nonetheless remain ambivalent and elitist in the way they orient to motherhood as a classed category. On the one hand, they can be seen as a form of transgressive political critique highlighting a representational style Hatherley (2018) refers to as a working class anti-Pygmalion aesthetics. On the other hand, however, and from a Bourdieusean perspective, they can be interpreted as disparaging the tastes of low class women, bringing class distinctions into even sharper focus.

In the next chapter, Axel Schmidt and Konstanze Marx turn to so-called Let's Plays; these are videos hosted on, say, YouTube where gamers present and comment on their first-hand games. The communicative setting is highly complex with the gaming presented for an absent audience but, for example, with a so-called facecam where the gamer is made visible as well as with sidebars for chatting about the game. All of which makes the matter of participation framework (Goffman, 1981) particularly interesting. For the audiences of Let's Plays, the games are obviously not playable, but they do need to be rendered entertaining or watchable. Indeed, as the authors note, these are one of the fastest-growing and least-studied kinds of fan production and one of the most successful genres on YouTube. It is for this reason that Schmidt \& Marx seek to establish how precisely players make the games so watchable for viewers. To this end, they document how players use a combination of verbal and visual means to reintegrate interactivity and make the product immersive again. One pervasive practice is the formulation by players of their own actions, much of which is accomplished visually although ultimately multimodally. In fact, it cannot be conveyed solely through the visuals; verbal resources are needed for transforming the stream of visual events into a comprehensible trajectory of action. 
In her chapter, Dorottya Cserző analyses virtual tours, a new practice made possible by the development and popularity of videochat. Today, videochat is available through a variety of platforms - most notably Skype and FaceTime - on a range of devices such as laptops, tablets and smartphones. In fact, the devices used make it increasingly easy to move around during a videochat session; as such, users can give each other virtual tours by moving the camera around to show off their environment. Through a systematic analysis of the structure of a virtual tour, Cserző documents the resources available to videochat users and the interactional functions of virtual tours. The main theoretical framework she uses is multimodal interaction analysis informed by nexus analysis - also sometimes referred to as mediated discourse analysis (Norris \& Jones, 2005). This kind of approach combines the micro-analysis of speech, camera movement, gesture, posture, and gaze with a broader consideration for the materiality of devices, locations and bodies. Specifically, her analysis focuses on a recorded videochat session between Kate and Charlie, during which Charlie gives a virtual tour to his sister Kate. Cserző presents the virtual tour using a multimodal transcript combining conversation analysis and screenshots from the video. She shows how the camera movement is co-ordinated with Charlie's commentary and Kate's responses to create a coherent virtual tour. As the various features of the room are shown and framed, each one is jointly evaluated. It is in this way that Charlie and Kate align with each other by forming a shared stance. Amongst other things, Cserző shows how pointing the camera is a powerful interactional resource for directing attention in a way that is not possible in face to face interaction. Inevitably, however, the 'shower' must frame what is shown with verbal commentary, making the tours fully multimodal accomplishments.

In their chapter, Rebecca Venema and Katharina Lobinger examine the role and relevance of visual communication in these close social relationships. The taking and sharing of photos has, of course, become a highly routine part of people's lives and is fully integrated into their everyday interactions. Indeed, this is nowadays one of the key ways many social relationships are created and maintained. In this regard, Venema \& Lobinger present a qualitative study of the way photos are used, both symbolically and as material objects, in couples' and friends' relationships. They take a cross-media approach which is grounded in the notions of 'polymedia' and repertoire-oriented media. A repertoire-oriented approach surfaces the role of visuals/visual interactions in the context of respondents' general communicative routines. Empirically speaking, they draw on 34 problem-focused, semi-structured single- and pair-interviews, applying qualitative thematic coding. Their findings confirm how pictures are essential resources for both couples and friends, but with differences in the way images are 
shared and integrated into everyday interactions. In fact, their findings run somewhat contrary to public debates about the negative implications of changing visual practices for social relationships. Photo-sharing is clearly used for the purposes of self-expression and self-representation. Photos also serve as materialized memories and thus another important emotional resource for couples/ friends. Ultimately, as Venema \& Lobinger show, this kind of visual communication is key for upholding relationships, not least because photo-sharing facilitates the maintenance of proximity, shared experiences and mutual bonds.

Opening Part 3 of the volume, Hartmut Stöckl proposes an explanation of image-centricity as a vital concept in multimodality research and reflects on its implications for media and genre. The central argument is that image-centric practices are crucially shaped by the technological and social affordances of media. Consequently, for example, Twitter or Instagram are likely to promote different multimodal genres and types of image-centricity as compared with magazine or newspaper articles. Based on widely accepted mediated and situational factors (see Herring, 2007), Stöckl sketches the central differences between old/print media and new/social media. These differences are used in a second step to develop general hypotheses about how the design of imagecentric genres and practices are likely to differ - observations that may guide empirical research with large data sets. He concludes by offering some brief, rough-and-ready suggestions for studying image-centric media and communication. The chapter starts with a critical examination of image-centricity as redeveloped from Caple's (2008) earlier notion of image-nuclearity. The centricity of images involves their compositional and perceptual dominance on the one hand, and their semantic and conceptual centrality on the other hand. He then teases out key mediational differences between print and social media, noting how both show signs of an increasing variety of image-centric genres. In this regard, Stöckl observes some of the typical features of social media which strongly affect image-centric practices and differ greatly from old-style print media: collaborative sharing of co-constructed messages, modal richness, a strong social indexicality of semiotic choices, and flexible/fast-paced message formats. Ultimately, he argues that image-centricity is not a newly 'emergent' trait in social media but one that is very 'familiar' from old media and that may be 'reconfigured' (Herring, 2013) through shareability, heightened media convergence and resignification in what Jucker \& Dürscheid (2012) have previously labelled communicative act sequences.

In the next chapter, Lara Portmann examines the way food and foodways are visualized in social media; eating is of course a well-known site where judgements about taste are employed for boundary-marking and class status maintenance. As Bourdieu (1984: 5) famously notes, 'good taste' are matters of 
social distinction. With its strong emphasis on images, the photo-sharing platform Instagram is a perfect example of this practice. To this end, her chapter presents a social semiotic analysis of the corporate uses of Instagram by Switzerland's two major grocery chains, Coop and Migros. Combining visual content analysis and social semiotics, she offers first a quantitative-descriptive perspective on their posts and then a more qualitative-interpretive one, highlighting in particular the design and compositional meanings of photos. The quantitative results show how the foods depicted are largely mundane, unmarked, and decontextualized, which leads me to argue that in order to understand how these posts work; for this reason it becomes useful to look beyond what is shown and consider also how it is shown. In this regard, Portmann then discusses two visual-discursive tactics: materiality and modality. By deploying material attributes (e.g. marble surfaces or fabric napkins) and by using colour and texture, Coop and Migros aestheticize otherwise quite ordinary foods. By emphasising form over function in this way, these corporations construct privileged eating practices. For all their claims to participatory democracy or egalitarianism, these strategic uses of social media effectively reinforce social hierarchies of taste. Portmann argues that 'intangible' semiotic strategies like visual materiality and modality, when positioned vis-à-vis supposedly unambiguous representational resources like written language, can be used to 'fashion' banal goods in ways which both construct and obfuscate privilege.

In her chapter, Jana Pflaeging turns our attention to the world of so-called viral content providers (or aggregators) on Facebook - in particular, one called Distractify. Her specific interest lies in the genre known as the 'listicle' which Wikipedia hurriedly defines as short-form writing which uses a list as its thematic structure. Pflaeging's data comprise two sets of 50 exemplars of listicles elicited from Distractify in 2014 and 2017. She examines these materials through a diachronic approach to viral online genres, implemented through a multi-layer analysis of the genre's communicative situation, textual function, and (structural/ rhetorical) multimodal composition. On this basis she identifies some general but revealing communicative trends. In 2014, for example, Distractify published articles such as The 16 Greatest Battles Fought By The Most Courageous Cats Of Our Time in list form. These multimodal documents were composed of $\overline{\mathrm{x}}=19.2$ listitems typically employing a structurally and rhetorically central photograph, video, or GIF. Listicles show only few traces of a narrative discourse structure; instead, they present - often in no particular order - a spectrum of visual associations that Facebook users can enjoy. By 2017, however, the page space of listicles had been significantly reorganized with a noticeable decrease in visualization intensity and a list-logic that was no longer structurally or rhetorically maintained. Instead, in the 2017 subset (e.g. A Guy Ordered One Slice Of Cheese From 
McDonald's And Twitter Lost It) were typically organized around long stretches of running text with an abundant embedding of topically-related Tweets used for narrating a single social occurrence. In effect, therefore, Distractify had turned to story-telling and this entailed a shift from image-centricity (see Stöckl, this volume) to word-centricity. It is in this way that Pflaeging documents an 'evolution' in viral online genres, one which shows how the design of their textual surfaces can change swiftly. This, she argues, also evidences a continual oscillation between commercial and interpersonal interests.

As the final chapter, Dorothee Meer and Katharina Staubach consider hugely popular 'haul' videos (or just hauls) posted on YouTube by so called social media influencers. Here, a person (usually young and female) presents their latest purchases to an audience of young, mainly female people. The authors present hauls as a digitally mediated form of osmotic advertising (after Katheder, 2008); unlike conventional print or TV advertising, young followers come to trust social media influencers as experts but also as peers or friends. Meer and Staubach's analysis focuses on the multimodal production of credibility in a case-study haul posted by the very successful German social media influencer Dagi Bee. In doing so, they attend closely to the parasocial (Horton and Wohl, 1956) strategies Dagi Bee uses for connecting with viewers. For example, they consider how she creates a tangibly shared living (i.e. bedroom) space, thereby staging herself as an older sister or friend. All of which makes her product recommendations more credible: friendly advice given by an older, more competent friend. Having said which, the authors also argue that Dagi Bee bears the hallmarks of a trickster (in Lévi-Strauss's, 1955, terms) as she leaves the amateur frame of the bedroom for an altogether more professional frame (e.g. posing like a model). Ultimately, though, her teenage fans/viewers are inclined to believe her recommendations because they experience her, on the one hand, as the trustworthy peer of roughly the same age, and on the other hand, as an expert in the field of fashion.

Acknowledgements: We take this opportunity to offer some important words of thanks which we do also on behalf of our esteemed colleague Federica who died in August 2019 after a serious illness. First and foremost, we are indebted to the Swiss National Science Foundation (SNSF Sinergia: CRSII1_160714) whose funding made possible the 2017 conference in Neuchâtel which was the impetus for the current volume. In this regard, we are enormously grateful to Etienne Morel, Christina Siever and Vanessa Jaroski who, as (post-)doctoral researchers on the SNSF project, oversaw so much of the conference organization. We offer special thanks to Crispin's student assistant Nicolas Rötlisberger for his meticulous, patient help with preparing the manuscript. Thanks are likewise due to Gwynne 
Mapes, also at the University of Bern, for her last-minute editorial assistance with some of the chapters. We also thank Kirstin Börgen and Lukas Lehmann at De Gruyter for their patient, hands-on support. Finally, we are pleased to have the chance to acknowledge the indispensable, constant support of Elisabeth Stark and Simone Ueberwasser as, respectively, principal investigator and coordinator of the What's up, Switzerland? project - thank you, dear colleagues.

\section{References}

Albert, Georg. 2015. Semiotik und Syntax von Emoticons. Zeitschrift für angewandte Linguistik 62(1). 3-22.

Androutsopoulos, Jannis (ed.). 2006. Sociolinguistics and computer-mediated communication. Special Issue of Journal of Sociolinguistics 10(4).

Androutsopoulos, Jannis. 2011a. Language change and digital media: A review of conceptions and evidence. In Tore Kristiansen \& Nik Coupland (eds.), Standard Languages and Language Standards in a Changing Europe, 145-161. Oslo: Novus.

Androutsopoulos, Jannis. 2011b. From variation to heteroglossia in the study of computermediated discourse. In Crispin Thurlow \& Kristine Mroczek (eds.), Digital Discourse: Language in the New Media, 277-298. New York: Oxford University Press.

Androutsopoulos, Jannis \& Michael Beißwenger (eds.). 2008. Data and methods in computermediated discourse analysis. Special Issue of Language@Internet 5.

Androutsopoulos, Jannis \& Jana Tereick. 2015. Youtube: Language and discourse practices in participatory culture. In Alexandra Georgakopoulou \& Teresa Spilioti (eds.), The Routledge Handbook of Language and Communication, 354-370. Abingdon: Routledge.

Baron, Naomi. (2010). Always on: Language in an online and digital world. New York: Oxford University Press.

Bou-Franch, Patricia \& Pilar Garcés-Conejos Blitvich (eds.). 2019. Analyzing Digital Discourse. New Insights and Future Directions. London: Palgrave Macmillan.

Bourdieu, Pierre. (1984). Distinction: A Social Critique of the Judgement of Taste (trans. $\mathrm{R}$ Nice). Cambridge, MA: Harvard University Press.

Caple, Helen. 2008. Intermodal relations in image-nuclear news stories. In Len Unsworth (ed.), Multimodal Semiotics. Functional Analysis in the Contexts of Education, 125-138. London: Continuum.

Danesi, Marcel. 2016. Language, society and new media sociolinguistics today. New York: Routledge.

Duchêne, Alexandre \& Monica Heller. 2007. Discourses of endangerment: Sociolinguistics, globalization and social order. In Alexandre Duchêne \& Monica Heller (eds.), Discourses of Endangerment: Interest and Ideology in the Defense of Languages, 1-13. London: Continuum.

Dürscheid, Christa \& Christina M. Siever. 2017. Jenseits des Alphabets - Kommunikation mit Emojis. Zeitschrift für Germanistische Linguistik 45(2),256-285.

Dürscheid, Christa, Franc Wagner \& Sarah Brommer. 2010. Wie Jugendliche schreiben. Schreibkompetenz und neue Medien. Berlin: De Gruyter. 
Georgakopoulou, Alexandra \& Tereza Spilioti (eds). 2015a. The Routledge Handbook of Language and Digital Communication. London: Routledge.

Georgakopoulou, Alexandra \& Tereza Spilioti (eds). 2015b. Introduction. In Alexandra Georgakopoulou \& Tereza Spilioti (eds), Handbook of Language and Digital Communication, 1-16. London: Routledge.

Goffman, Erving. 1981. Footing. In Ervin Goffman (ed.), Forms of talk, 124-159. Philadelphia: University of Pennsylvania Press.

Hatherley, Frances. 2018. A working-class anti-Pygmalion aesthetics of the female grotesque in the photographs of Richard Billingham. European Journal of Women's Studies 25(3), 355-370.

Heidegger, Martin. 2008. Being and Time, Reprint edn. New York: Harper Perennial Modern Classics.

Herring, Susan C. 2007. A Faceted Classification Scheme for Computer-Mediated Discourse. language@internet 4.

Herring, Susan C. 2013. Discourse in Web 2.0: Familiar, reconfigured, and emergent. In Deborah Tannen \& Anna Marie Trester (eds.), Georgetown University Round Table on Languages and Linguistics 2011: Discourse 2.0: Language and New Media, 1-25. Washington, DC: Georgetown University Press.

Herring, Susan C. 2015. New frontiers in interactive multimodal communication. In Alexandra Georgakopoulou \& Tereza Spilioti (eds), Handbook of Language and Digital Communication, 398-402. London: Routledge.

Horton, Donald \& Richard R. Wohl. 1956. Mass communication and para-social interaction: Observations on intimacy at a distance. Psychiatry 19, 215-229.

Ihde, Don. 2001. Bodies in Technology, 1st edn. Minneapolis: University of Minnesota Press. Jäntti, Saara, Tuija Saresma, Sirpa Leppänen, Suvi Järvinen \& Piia Varis. 2017. Homing blogs as ambivalent spaces for feminine agency. Feminist Media Studies 18(5), 888-904.

Jenkins, Henry. 2006. Convergence Culture: When Old and New Media Collide. New York NYU Press.

Jewitt, Carey. 2004. Multimodality and new communication technologies. In Philip Levine \& Ron Scollon (eds.), Discourse and Technology: Multimodal Discourse Analysis, 198-195. Washington, DC: Georgetown

Jones, Rodney H. 2009. Dancing, skating and sex: Action and text in the digital age. Journal of Applied Linguistics and Professional Practice 6(3), 283-302.

Jones, Rodney H., Alice Chik \& Christoph A. Hafner. 2015. Discourse and Digital Practices: Doing Discourse Analysis in the Digital Age. London: Routledge.

Jucker, Andreas H. \& Christa Dürscheid. 2012. The linguistics of keyboard-to-screen communication: A new terminological framework. Linguistik Online 56(6/12), 39-64.

Keane, Webb. 2003. Semiotics and the social analysis of material things. Language and Communication 23, 409-425.

Kress, Gunther. 2003. Literacy in the New Media Age. London: Routledge.

Kress, Gunther \& Theo van Leeuwen. 1996. Reading Images: The Grammar of Visual Design. London: Routledge.

Kress, Gunther \& Theo van Leeuwen. 2001. Multimodal Discourse - The Modes and Media of Contemporary Communication. London: Arnold.

Lévi-Strauss, Claude. (1955). The structural study of myth. Journal of American Folklore 68, 428-444. 
Mirzoeff, Nicholas. 2011. The Right to Look: A Counterhistory of Visuality. Durham, NC: Duke University Press Books.

Myers, Greg. 2010. The Discourse of Blogs and Wikis. London: Continuum.

Norris, Sigrid \& Rodney H. Jones (eds.). 2005. Discourse in Action: Introducing Mediated Discourse Analysis. London \& New York: Routledge.

Rascol, Stephanie. 2017. L'évolution de l'utilisation des emojis de la sphere privée à la sphere publique. Université Paul-Valéry Montpellier 3.

Scollon, Ron. 2001. Mediated Discourse: The Nexus of Practice. Routledge.

Squires, Lauren. 2010. Enregistering internet language. Language in Society 39(4), 457-492.

Squires, Lauren (ed.). 2018. English in Computer-Mediated Communication: Variation, Representation, and Change. Berlin: De Gruyter.

Thurlow, Crispin. 2006. From statistical panic to moral panic: The metadiscursive construction and popular exaggeration of new media language in the print media. Journal of Computer-Mediated Communication 11(3).

Thurlow, Crispin. 2014. Disciplining youth: Language ideologies and new technologies. In Adam Jaworski \& Nikolas Coupland (eds.), The Discourse Reader. 3rd edn., 481-496. London: Routledge.

Thurlow, Crispin. 2017. "Forget about the words"? Tracking the language, media and semiotic ideologies of digital discourse: The case of sexting. Discourse, Context \& Media 20, 10-19.

Thurlow, Crispin. 2018. Digital discourse: Locating language in new/social media. In Jean Burgess, Thomas Poell \& Alice Marwick (eds.), The Sage Handbook of Social Media, 135-145. New York, NY: Sage.

Thurlow, Crispin, Giorgia Aiello and Lara Portmann. 2019. Visualizing teens and technology: A social semiotic analysis stock photography and news media imagery. New Media \& Society. doi.org/10.1177/1461444819867318

Thurlow, Crispin \& Adam Jaworski. 2017. Introducing elite discourse: The rhetorics of status, privilege, and power. Social Semiotics 27(3), 243-254.

Thurlow, Crispin \& Kristine Mroczek. 2011. Digital Discourse: Language in the New Media. New York: Oxford University Press.

Ueberwasser, Simone \& Elisabeth Stark. 2017. What's up, Switzerland? A corpus-based research project in a multilingual country. Linguistik Online 84(5).

Vaisman, Carmel L. 2014. Beautiful script, cute spelling and glamorous words: Doing girlhood through language playfulness on Israeli blogs. Language \& Communication 34, 69-80. 
